\title{
Overdentures as an alternative to conventional dentures: a micro-costing analysis for Public Health Service in Brazil
}

\author{
Overdentures como alternativa às próteses convencionais: \\ uma análise de micro-custeio para o Sistema Único de Saúde
}

Denise de Fátima Barros Cavalcante (https://orcid.org/0000-0002-9166-0367) ${ }^{1}$

Antonio Carlos Pereira (https://orcid.org/0000-0003-1703-8171) ${ }^{1}$

Yuri Wanderley Cavalcanti (https://orcid.org/0000-0002-3570-9904) ${ }^{2}$

Livia Fernandes Probst (https://orcid.org/0000-0002-4696-0862) ${ }^{3}$

Gláucia Maria Bovi Ambrosano (https://orcid.org/0000-0001-5950-6370) ${ }^{1}$
${ }^{1}$ Faculdade de Odontologia de Piracicaba, Universidade Estadual de Campinas. Av. Limeira 901, Areião. 13414-903 Piracicaba SP Brasil.dradenisecavalcante@ gmail.com

${ }^{2}$ Centro de Ciências da Saúde, Departamento de Odontologia Clínica e Social, Universidade Federal da Paraíba. João Pessoa PB Brasil.

${ }^{3}$ Unidade Avaliação de Tecnologias em Saúde (UATS), Hospital Alemão Oswaldo Cruz (HAOC) São Paulo SP Brasil.

\begin{abstract}
This study aimed to estimate cost and compatibility with public financial incentives of two technologies for treating the edentulous mandible: lower complete dentures $(C D)$ and overdentures retained by two dental implants (OD). This study consisted of a partial economic evaluation, with a micro-costing bottom-up approach for the calculation of direct costs. The estimates involved the number of consultations, proportion of materials, equipment, instruments' lifetime, and human resources, described in the price panel website of the Ministry of Economy in Brazil. Complementary information was obtained from a panel of experts. A sensitivity analysis was based on $20 \%$ variation. The estimated cost of a $C D$ was $R \$ 189.89$ (base scenario), and this varied between $R \$ 151.91$ and $R \$ 227.89$ according to sensibility analysis. The cost of an OD was $R \$$ 663.05 (ranging from $R \$ 795.66$ to $R \$ 530.44$ $1 U S=R \$ 3.80 / J u l y$ 2019). The Ministry of Health covers appropriately the costs of the $C D$ and $O D$. Both technologies showed costs that are within the limits of financial public incentives obtained by municipalities. The technologies are economically viable and should be induced through public policies due to their positive impacts on several functional domains of health.
\end{abstract}

Key words Economic evaluation, Micro costing, Denture, Overdenture
Resumo Estimar os custos e a compatibilidade dos incentivos públicos de duas tecnologias para o tratamento da mandíbula edêntula: prótese total convencional (PTC) e overdenture retida por dois implantes (OD). Este estudo consistiu em uma avaliação econômica parcial, com abordagem "bottom-up" para o cálculo dos custos diretos. As estimativas levaram em consideração o número de consultas, proporção de materiais, equipamentos, vida útil dos instrumentais e recursos humanos. Os custos foram baseados no painel de preços do Ministério da Economia do Brasil e informações complementares foram obtidas de um painel de especialistas. Uma análise de sensibilidade foi baseada na variação de $20 \%$ dos custos. Os custos da PTC foram estimados em $R \$ 189,89$ (cenário base) com variação entre $R \$ 151,91$ e $R \$$ 227,89 na análise de sensibilidade. Os custos da $O D$ foram $R \$ 663,05$ (variando de $R \$ 795,66$ a $R \$ 530,44)$. O Ministério da Saúde cobre apropriadamente os custos de ambas as tecnologias nos cenários base e mais otimista. Ambas as tecnologias apresentaram custos dentro dos limites dos incentivos públicos recebidos. As tecnologias são economicamente viáveis e devem ser induzidas por políticas públicas diante do impacto positivo em vários dominios funcionais da saúde.

Palavras-chave Avaliação Econômica, Microcusteio, Dentadura, Overdenture 


\section{Introduction}

The financing system of the public health sector in Brazil isregulated by different laws. Diverse strategies have limited the financing and expenditure towardspublic health in Brazil. These measures result from a peculiar political-economic scenario, caused by a severe economic recession, with a reduction in the Gross National Product (GNP) by approximately 6\% from 2014 to 2017. This context has resulted in a breakdown of the Ministry of Health policies, due to the constant changes, which have not always been compatible with the collective interests. Furthermore, 70\% of the population is dependent on the Brazilian public health system (known as SUS) ${ }^{1}$.

Making the public health system more efficient maximizes the health service and makes expenditures more rational. In this context, demand shows an upward trend and resources progressively fall ${ }^{2}$. Based on that, it is important to consider that economic studies must guide managers into rational decisions. Nevertheless, the production of economic evaluation studies with application to the Brazilian public health system (SUS) has been modest ${ }^{3,4}$, so the costs analysis in oral health are rare ${ }^{5,6}$.

The National Policy on Oral Health (known as Smiling Brazil Program) has supported the oral health care in Brazil since 2004. However, a reduction in the provision of oral health care over many years resulted in the accumulation of oral diseases, including the high prevalence of tooth $\operatorname{loss}^{7}$.To minimize the impact of tooth loss, conventional dentures have been offered within the perspective of public health system. However, the last national oral health survey in Brazil (2010) showed that the percentage of elderly people that wear conventional complete upper dentures was around $60 \%$, while the use of conventional complete lower dentures was around $40 \%{ }^{8,9}$.

The use of lower dentures among the elderly was observed to be drastically lower, mainlydue to the retention. From this aspect, lower complete denturesretained by two implants (overdentures) is a minimum standard of care and a more efficient strategy for the treatment of edentulism in the elderly population dependent on the public health system ${ }^{10}$.

Edentulism negatively impacts facial esthetics, as a result of lowered labial commissures, reduced lip thickness, prognathic appearance, increase in the nasolabial sulcus, and reduced facial height ${ }^{11}$. It also affects mastication, speech, smiling, social life and intimate relationships ${ }^{12}$.
The funds for oral rehabilitation with conventional complete dentures have been provided by the public health system in Brazil since 2005; and the budget transfer regulation for this purpose was updated in $2012^{13}$. The provision of complete dentures retained by implants (overdentures) was then regulated in 2010 and the standards for service provision were updated in $2017^{14,15}$.

Rehabilitation with conventional lower dentures faces at least $35 \%$ of abandonment during the course of the first year ${ }^{16}$, in which patients report difficulty with adaptation, lesions in the mucosa, and pain ${ }^{17}$. The abandonment of complete dentures generates a waste of public resources. Overdentures are recognized to have better biomechanical properties, greater acceptance and bigger satisfaction when compared with complete dentures ${ }^{18,19}$. However, besides itscontraindication for systemically compromised individuals, this treatment involves some disadvantages, such as possible discomfort during implant placement, greater working time and higher global costs ${ }^{18,19-21}$. From the perspective of the public sector, an economical evaluation based on micro-costingwould aid in the decision making towards the public oral service.

Although there is consensus that the implant-retained prosthesis is the minimum standard of care for the edentulous mandible, this procedure has not disseminated at the public sector $^{22}$. Therefore, the aim of this study was to estimate the direct costsand compatibility with public financial incentives of two technologies: mandibular complete dentures $(\mathrm{CD})$ and overdentures (OD), from the perspective of municipalities.

\section{Methods}

The study was dismissed from the Ethics and Research Committee of Piracicaba Dental School, State University of Campinas (FOP-UNICAMP), because it is secondary data and available for public consultation.

This study included a partial economic evaluation in oral health with the bottom-up approach. Direct costs for manufacturing lower conventional dentures and complete dentures retained by two implants (overdentures) were calculated from the perspective of the Brazilian public health system (SUS, through Smiling Brazil Program). Cost estimations were based on a hypothetical base case. 
The direct cost estimates involved three stages: (1) identification; (2) number; and (3) cost of the resources consumed. Thus, the resources used were identified and quantified in accordance with their use in the treatment, laboratory and maintenance stages, with monetary values being attributed to them.

The Microsoft Excel program was used to list the items needed forapplying the two technologies (CD and OD). A panel of specialists composed of five experienced professionals aligned and standardized the technique most used in the public health system for the two interventions. The estimated portions and times were based on the responses of the expert panel. Initially, the sequence of events was asked to define the clinical protocol. Portions, equipment and clinical procedures times were defined based on the consensus among experts. If there is no consensus, it checked up what most replied. There was no need to return to the experts (2nd review) to make a decision on the items surveyed.

Regarding the clinical protocol, some assumptions needed to be defined: a) panoramic radiography was the standard imaging exam defined; b) it was assumed the immediate loading protocol with installation of the attachment after the implant to be locked; c) the surgical technique was opened, with exposure of the bone border; d) the patient's prosthesis was duplicated in acrylic and used as a guide for surgery; e) the suture was removed in 1 week; $f$ ) the protocol did not use soft resurfacing and instructed the patient to be without prosthesis for at least 1 week; g) external hexagon implant and O-ring system were used.

A diagram of the steps proposed for the two technologies is illustrated in Figure 1. The two technologies were differentiated by the presence of a surgical stage and adaptation of lower denture, after finalization of the conventional complete denture.

All the steps necessary for manufacturing lower dentures were meticulously described in the Results consisting of all steps from the first clinical appointment, laboratory procedures and the denture placed. For this purpose, the micro-costing technique was used, where the inputs were attributed to each step, whether they were items of equipment, instruments, consumable materials, or human resources necessary for the conclusion of each step with its respective proportions, according to the quantity spent. In addition, the values of equipment and instruments were diluted according to their useful life, taking into consideration the values suggested by the manufacturer sand panel of specialists. Costs of dental implants and components were estimated using the concept of large-scale bids, in which a minimum of 500 items is purchased. Similarly, the micro-costing technique was used for calculating the costs of items necessary for surgery, considering the placement of 2 mandibular implants, in addition to the time spent on relining, adaptation and placement of the original conventional dentures (re-used at this time).

The second step consisted of consulting the most assertive sources of information to obtain a realistic and unique national value for each item. In this step, web search involved two websites: the health price bank (http://portalms.saude.gov.br/ gestao-do-sus/economia-da-saude/banco-deprecos-em-saude) and the panel of prices site from the Ministry of Planning, Development and Management (http://paineldeprecos.planejamento.gov.br/). On the first website, the municipalities and states submit their bid documents to the system, generating a file of budget items throughout Brazil. For the items that did not necessarily constitute a health component, such as a paper towel, the website of the Ministry of Planning was searched for prices of materials and services (cost per hour of dentists, oral health assistant and dental prosthesis technician).

Costs were adjusted according to the number of disposable items used per consultation, as well as for diluted costs for permanent long-term use items. Considering the number of clinical appointments per day, the panel of specialists informed a range of 8 to 14 . This study considered 10 consultations per day as the mean number of attendances performed by a regular dentist within the public sector. The values for estimating the calculation of micro-costing for human resources (dentist and assistant) were based on the value of the clinical hour, that is, the value of the average monthly salary of the professional (http:// paineldeprecos.planejamento.gov.br/) was determined and divided by the average number of days (22) and hours worked per day (8).

No discounts and corrections for inflation were used because this economical evaluation has not a temporal context. Since only direct costs were considered, no information was included about costs pertinent to other perspectives of analysis, such as reimbursements to patients or families (out-of-pocket costs) and indirect costs, such as loss of productivity due to time spent on treatment. Building, equipment and technology (complete mandibular denture and overdenture) 

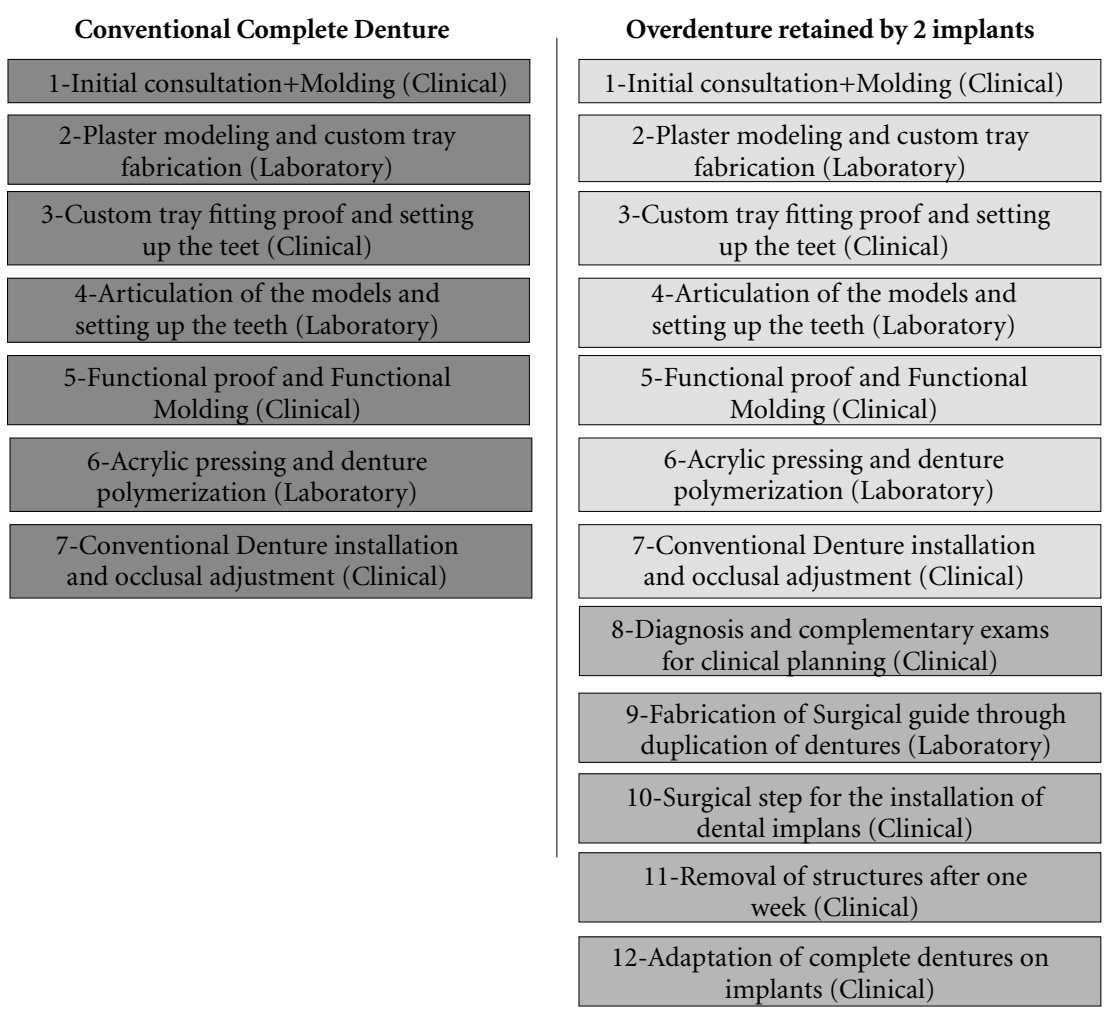

Figure 1. Clinical and Laboratory steps for conventional complete dentures manufacturing and for construction of overdentures retained by two implants.

Source: Elaborated by the authors.

maintenance costs were also not calculated, considering that the development of these technologies demands the use of dental specialty centers, regional dental prosthesis laboratory (public dental prosthesis laboratory), and oral health teams in primary care; these teams already have the physical structure necessary for their actions.

A sensitivity analysis was carried out. Estimated values could vary $20 \%$ more (more pessimistic scenario) to $20 \%$ less (more optimistic scenario $)^{23}$.

\section{Results}

Table 1 shows the costs forlower dentures manufacturing, according to each stage of denture manufacturing ( 1 US $\$=\mathrm{R} \$ 3.80$ in July 16, 2019). The entire micro-costing technique was based on direct costs (Human resources, materials, instru- ments and equipment). The major part of the cost was directed to human resources ( $\mathrm{R} \$ 142.12$, or US\$ 37.4 , as $74.85 \%$ of the total), divided into Clinical work ( $\mathrm{R} \$ 82.80$, or US\$21.79, as $43.6 \%$ of the total) and Laboratory work ( $\mathrm{R} \$ 59.32$, or US\$ 15.61 , as $31.2 \%$ of the total). The costs of material, instruments and equipment were $\mathrm{R} \$$ 47.75 (US\$, 12.56 , as $25.15 \%$ of the total). The total cost of a lower denture was estimated at $\mathrm{R} \$ 189.89$ (US\$ 49.97).

Table 2 shows the costs for manufacturing of an overdenture (implant-retained denture). The total costs were estimated at R $\$ 473.16$ (US\$ 124.51) for the technique with 2 implants, being $23 \%$ (R\$ 109.44, or US\$28.80) spent on human resources and $77 \%(\mathrm{R} \$ 363.72$, or US\$ 95.72) on materials, equipment, instruments and exams. The highest percentage of expenditure was concentrated on implants and prosthetic components (R\$ 280.00, or US\$ 73.68, as 59,17\% of the total). 
Table 1. Micro costing of conventional complete denture (CD), according to each clinical and laboratory step, involved human resource, type of resource and associated costs. Costs are presented in Brazilian Reais ( 1 US $\$=\mathrm{R} \$$ $3.80)$.

\begin{tabular}{|c|c|c|c|c|c|}
\hline & \multicolumn{2}{|c|}{ Clinical and Laboratory steps } & \multirow{3}{*}{$\begin{array}{c}\begin{array}{c}\text { Human } \\
\text { Resources }\end{array} \\
\text { Dentist }\end{array}$} & Type of Resource & \multirow{2}{*}{$\begin{array}{c}\begin{array}{c}\text { Associated } \\
\text { costs }(\mathbf{R} \$)\end{array} \\
3.52\end{array}$} \\
\hline 1 & Initial Molding/Impression & Clinical & & $\begin{array}{l}\text { Materials, Instruments, } \\
\text { and Equipment }\end{array}$ & \\
\hline & & & & Human Resources & 16.56 \\
\hline \multirow[t]{2}{*}{2} & $\begin{array}{l}\text { Pouring the model and custom } \\
\text { tray manufacturing }\end{array}$ & Laboratory & $\begin{array}{l}\text { Dental Prosthesis } \\
\text { Technician }\end{array}$ & $\begin{array}{l}\text { Materials, Instruments, } \\
\text { and Equipment }\end{array}$ & 7.75 \\
\hline & & & & Human Resources & 21.05 \\
\hline \multirow[t]{2}{*}{3} & $\begin{array}{l}\text { Wax registry and fitting proof of } \\
\text { custom tray }\end{array}$ & Clinical & Dentist & $\begin{array}{l}\text { Materials, Instruments, } \\
\text { and Equipment }\end{array}$ & 1.16 \\
\hline & & & & Human Resources & 24.84 \\
\hline \multirow[t]{2}{*}{4} & $\begin{array}{l}\text { Articulation of the models and } \\
\text { setting up the teeth }\end{array}$ & Laboratory & $\begin{array}{l}\text { Dental Prosthesis } \\
\text { Technician }\end{array}$ & $\begin{array}{l}\text { Materials, Instruments, } \\
\text { and Equipment }\end{array}$ & 13.69 \\
\hline & & & & Human Resources & 19.14 \\
\hline \multirow[t]{2}{*}{5} & $\begin{array}{l}\text { Functional proof and Functional } \\
\text { Molding }\end{array}$ & Clinical & Dentist & $\begin{array}{l}\text { Materials, Instruments, } \\
\text { and Equipment }\end{array}$ & 4.83 \\
\hline & & & & Human Resources & 24.84 \\
\hline \multirow[t]{2}{*}{6} & $\begin{array}{l}\text { Acrylic pressing and denture } \\
\text { polymerization }\end{array}$ & Laboratory & $\begin{array}{l}\text { Dental Prosthesis } \\
\text { Technician }\end{array}$ & $\begin{array}{l}\text { Materials, Instruments, } \\
\text { and Equipment }\end{array}$ & 6.83 \\
\hline & & & & Human Resources & 19.14 \\
\hline \multirow[t]{2}{*}{7} & Denture installation & Clinical & Dentist & $\begin{array}{l}\text { Materials, Instruments, } \\
\text { and Equipment }\end{array}$ & 4.35 \\
\hline & & & & Human Resources & 16.56 \\
\hline & ividual protection equipment & & All & Materials & 5.63 \\
\hline \multicolumn{5}{|c|}{ Global Costs for Conventional Complete Denture Manufacturing (R\$) } & 189.89 \\
\hline \multicolumn{5}{|c|}{ Global Costs for Conventional Complete Denture manufacturing (US\$) } & 49.97 \\
\hline
\end{tabular}

Source: Elaborated by the authors.

Table 2. Micro costing of Overdenture (complete denture retained by two implants), according to each clinical and laboratory step, involved human resource, type of resource and associated costs. Costs are presented in Brazilian Reais (1 US\$=R \$ 3.80).

\begin{tabular}{|c|c|c|c|c|c|}
\hline & \multicolumn{2}{|c|}{ Clinical and Laboratory steps } & \multirow{2}{*}{$\begin{array}{l}\text { Human Resources } \\
\text { Dentist and Dental } \\
\text { ProsthesisTechnician }\end{array}$} & \multirow{2}{*}{\begin{tabular}{l}
\multicolumn{1}{c}{ Type of Resource } \\
Conventional Complete \\
Denture
\end{tabular}} & \multirow{2}{*}{$\begin{array}{r}\begin{array}{r}\text { Associated } \\
\text { costs }(\mathbf{R} \$)\end{array} \\
189.89\end{array}$} \\
\hline 1 to 7 & $\begin{array}{l}\text { Steps from conventional } \\
\text { denture manufacturing }\end{array}$ & $\begin{array}{l}\text { Clinical and } \\
\text { Laboratory }\end{array}$ & & & \\
\hline 8 & $\begin{array}{l}\text { Diagnosis and } \\
\text { complementary exams }\end{array}$ & Clinical & Dentist & $\begin{array}{l}\text { Complementary Exams } \\
\text { Human Resources }\end{array}$ & $\begin{array}{r}30.00 \\
8.28\end{array}$ \\
\hline 9 & $\begin{array}{l}\text { Fabrication of surgical } \\
\text { guide }\end{array}$ & Laboratory & $\begin{array}{l}\text { Prosthesis } \\
\text { Technician }\end{array}$ & Materials and Lab time & 27.48 \\
\hline \multirow[t]{4}{*}{10} & \multirow{4}{*}{$\begin{array}{l}\text { Surgical step for the } \\
\text { installation of dental } \\
\text { implants }\end{array}$} & \multirow[t]{4}{*}{ Clinical } & \multirow[t]{4}{*}{ Dentist } & $\begin{array}{l}\text { Materials, Instrumentals } \\
\text { and Equipment }\end{array}$ & 26.22 \\
\hline & & & & Human Resources & 76.32 \\
\hline & & & & Dental Implants (x2) & 140.00 \\
\hline & & & & $\begin{array}{l}\text { Prosthetic Components } \\
(\mathrm{x} 2)\end{array}$ & 140.00 \\
\hline \multirow[t]{2}{*}{$11 / 12$} & \multirow[t]{2}{*}{$\begin{array}{l}\text { Removal of Sutures and } \\
\text { follow-up evaluation }\end{array}$} & \multirow[t]{2}{*}{ Clinical } & \multirow[t]{2}{*}{ Dentist } & $\begin{array}{l}\text { Materials, Instrumentals } \\
\text { and Equipment }\end{array}$ & 0.018 \\
\hline & & & & Human Resources & 8.28 \\
\hline \multicolumn{4}{|c|}{$\begin{array}{l}\text { Costs for Complete Denture adaptation on Implants (Overdenture } \\
\text { manufacturing from complete denture) }\end{array}$} & Total for steps 8 to $12(\mathrm{R} \$)$ & 473.16 \\
\hline \multicolumn{4}{|c|}{ Global Costs for Overdenture manufacturing ( $\mathrm{R} \$)$} & & 663.05 \\
\hline \multicolumn{4}{|c|}{ Global Costs for Overdenture manufacturing (US\$) } & & 174.49 \\
\hline
\end{tabular}


According to the sensitivity analysis (Table 3), the total costs for overdenture manufacturing varied between the most optimistic ( $\mathrm{R} \$ 530.44$, or US\$139.59) and the most pessimistic scenario ( $\mathrm{R} \$ 795.66$, or US\$ 209.38). In Table 4, we observe that financial incentives provided by the Ministry of Health are sufficient to cover the cost of an overdenture in most of the scenarios (exception on most pessimistic scenario of re-using complete denture).

\section{Discussion}

The decision process in public health depends on the decision to invest in a technology and do not invest in another, and this is considered as opportunity cost. Every decision must be based on the best evidence available, in which the best results of effectiveness or efficacy can be balanced with equivalent financial resources ${ }^{24}$.

In the present study, we have shown that the cost of human resources and permanent material for manufacturing a lower denture was $\mathrm{R} \$$ 189,89 (US\$ 49.97). This calculation considered that dentures would be manufactured either by a laboratory of the public sector itself or purchased from an outsourced laboratory ${ }^{12}$. This included the cost of human resources - the dentist, the oral health assistant (OHA), and the dental prosthesis technician (DPT) - and amounted to $\mathrm{R} \$ 142.12$ (US\$ 37.4 , as $74.8 \%$ of the total). This cost is below what would be spent if the municipality outsourced the laboratory work. A public dental prosthesis laboratory spends $\mathrm{R} \$ 59.32$ for each denture manufacturing, according to the micro-costing technique. In contrast, the values spent for outsourcing dentures tend to be high-

Table 3. Sensitivity analysis of conventional complete dentures and overdentures costs, withinthe Brazilian public health system perspective. Sensitivity analysis consisted of variation of base scenario into most optimistic (negative variation of costs in 20\%) and most pessimistic (positive variation of costs in 20\%) scenarios. Costs are presented in Brazilian Reais (1 US\$=R\$3.80).

\begin{tabular}{|c|c|c|c|c|}
\hline \multicolumn{2}{|c|}{ Technology and Scenarios } & \multirow{2}{*}{$\begin{array}{c}\begin{array}{c}\text { Human } \\
\text { Resources }\end{array} \\
\text { Costs (R\$) }\end{array}$} & \multirow{2}{*}{$\begin{array}{c}\text { Materials, } \\
\text { Instrumentals and } \\
\text { Equipment costs (R\$) } \\
47.76\end{array}$} & \multirow{2}{*}{$\begin{array}{l}\text { Global Costs (R\$) } \\
189.89 \text { (US\$ 49.97) }\end{array}$} \\
\hline Conventional & Base Scenario & & & \\
\hline Complete & Most Optimistic Scenario & 113.70 & 38.21 & 151.91(US\$ 39.97) \\
\hline Denture & Most Pessimistic Scenario & 170.54 & 57.31 & 227.85(US\$ 59.96) \\
\hline \multirow[t]{3}{*}{ Overdenture } & Base Scenario & 109.44 & 363.72 & $\begin{array}{c}189.89+473.16=663.05 \\
(\text { US\$ } 174.49)\end{array}$ \\
\hline & Most Optimistic Scenario & 87.55 & 290.98 & $\begin{array}{c}151.91+378.53=530.44 \\
(\text { US\$ 139.59) }\end{array}$ \\
\hline & Most Pessimistic Scenario & 131.33 & 436.46 & $\begin{array}{c}227.85+567.79=795.66 \\
(\text { US\$ 209.38) }\end{array}$ \\
\hline
\end{tabular}

Source: Elaborated by the authors.

Table 4. Costs for Overdenture provision within public health system, according to different clinical situations. Re-use of conventional denture was compared with the provision of overdenture as first treatment option for oral rehabilitation. Balance between costs for overdenture manufacturing and Ministry of Health transfer to municipalities was calculated within reference (base) and alternative (most optimistic and most pessimistic) scenarios. Costs are presented in Brazilian Reais (1 US\$=R $\$ 3.80)$.

\begin{tabular}{|c|c|c|c|c|}
\hline \multirow{2}{*}{$\begin{array}{l}\text { Clinical } \\
\text { Situation }\end{array}$} & \multirow{2}{*}{$\begin{array}{c}\text { Ministry of } \\
\text { Health Transfer }\end{array}$} & \multicolumn{3}{|c|}{ Global Costs for Overdenture provision within public health system } \\
\hline & & & & \\
\hline $\begin{array}{l}\text { e-use of } \\
\text { onventional }\end{array}$ & $\begin{array}{l}\mathrm{R} \$ 670 \\
(\mathrm{US} \$ 176.31)\end{array}$ & $\begin{array}{l}\text { Differ } \\
\mathrm{R} \$ 6 .\end{array}$ & $\begin{array}{l}\text { Cost } \\
\text { Diffe } \\
\text { R\$1 }\end{array}$ & $\begin{array}{l}\text { Cost } \\
\text { Diffe } \\
\text { R \$ - }\end{array}$ \\
\hline $\begin{array}{l}\text { Overdenture } \\
\text { as first } \\
\text { choice }\end{array}$ & $\begin{array}{l}\mathrm{R} \$ 820 \\
\text { (US\$ } 215.79 \text { ) }\end{array}$ & $\begin{array}{l}\text { Costs: R\$ } 663.05 \text { (US\$ 174.49) } \\
\text { Difference from transfer: } \\
\text { R\$ } 156.95 \text { (US\$ 41.30) }\end{array}$ & $\begin{array}{l}\text { Costs: R\$ } 530.44 \text { (US\$ 139.59) } \\
\text { Difference from transfer: } \\
\mathrm{R} \$ 289.56 \text { (US\$ } 76.20 \text { ) }\end{array}$ & $\begin{array}{l}\text { US\$ 209.38) } \\
\text { ansfer: } \\
\text { 1) }\end{array}$ \\
\hline
\end{tabular}

Source: Elaborated by the authors. 
er than R\$210,00 (US\$ 55.26, as mean values of 11 proposals found in the Brazilian Price Bank), which corresponds to an additional cost of R\$ 150.68 (US\$ 39.65) per denture.

In Brazil, depending on the number of dentures manufactured, the Ministry of Health provides the municipalities with financial incentive for the technologies. The municipality that manufactures 121 prosthesis per month $(1,452$ dentures per year) receives R\$270,072.00 (US\$ $71,071.58)$ per year, which represents $\mathrm{R} \$ 186.00$ (US\$ 48.95) per denture (mean transfer for average production above 120 prostheses $)^{12}$. Then, considering the micro-costing of lower denture obtained from the present study ( $\mathrm{R} \$ 189.89$, or US\$ 49.97), it could be said that global costs of denture manufacturing ( $\mathrm{R} \$ 275,720.28$, or US\$ $72,557.97$ ) are almost fully covered by the Ministry of Health in Brazil, since municipalities manufacture dentures within the public health system. If municipalities transferred the responsibility to private laboratories, additional costs of R\$ 150.68 (US\$ 39.65) per denture would be generated, representing an increase of $\mathrm{R} \$ 218,787.36$ (US\$ 57,575.62) in expenditure per year in a private laboratory (considering 121 dentures per month and 1452 denture per year).

It is worth emphasizing that costs calculated through the micro-costing technique would possibly be even lower, considering that some equipment and instruments had their lifetime underestimated in the present study. Most of items are used for a longer period than that established for the present study; however, authors chose to adopt a more conservative position.

In comparison with lower dentures, the public incentive for overdenture manufacturing is more advantageous. The Ministry of Health transfers R\$ 260,00 for each implant and R\$ 300,00 (US\$ 78.95) for the implant-retained prosthesis, which represents a global transfer of $\mathrm{R} \$ 820,00$ (US\$ 215.79) ${ }^{13}$, since the first choice is to install two implants and an overdenture. However, the lower denture is frequently the first choice to most of patients from the public sector. In those cases, a considerable percentage of patients usually do not get to use lower dentures after a few weeks. Based on that, the lower dentures can be adapted over two implants. In this case, the amount transferred by the Ministry of Health is R $\$ 670,00$ (US\$ 176.31 , being R\$260,00 - US\$ 68.42 for each implant and R\$ 150,00 - US\$ 39.47 for the lower denture).

The overdenture costs obtained through the micro-costing technique ranged from $\mathrm{R} \$ 530.44$ to R\$ 795.66 (from US\$ 139.59 to US\$ 209.38), most of which is aimed at implants and components ( R \$ 280.00, or US\$ 73.68, as $59.17 \%$ of the total). Although the items of equipment have a high initial cost, these costs are diluted according to the duration of use, making the technique more attractive for the public sector. Thus, oral rehabilitation with overdentures could be considered economically feasible with minimal financing supported by municipality. In this case overdenture is the first treatment option for rehabilitation of edentulous individuals, the difference between public incentives and global costs varies from $\mathrm{R} \$ 24.34$ to $\mathrm{R} \$ 289.56$ (US\$ 6.41 to US\$ 76.20) being a clearly economically viable alternative. If the original lower denture is reused to manufacture an overdenture, a positive balance is observed in base and most optimistic scenarios (economical margin of $\mathrm{R} \$ 139.56$ to $\mathrm{R} \$-125.66$, or US\$ 36.72 to US\$ -33.07). Taking into account the assumptions and clinical protocol defined for this study, we can assume that overdentures could be considered a therapeutic option in terms of costs for prosthetic rehabilitation from the perspective of SUS, which can be observed in some municipal experiences in Brazil.

The lower denture is frequently abandoned due to various factors, such as misfit, lesions, and pain ${ }^{16,19,24,25}$. The impact of lower denture abandonment within the public health system was not estimated before; however, based on previous findings, it is assumed that $35 \%$ of all edentulous individuals that receive lower dentures stop using them within the first year ${ }^{15}$. This means that resources directed to the manufacturing of lower dentures are wasted. Therefore, one of the options for improving this economic requisite would be the incorporation of a surgical stage with implantation of two dental implants and later adaptation of the pre-existent denture on the implants. This would increase the survival rate of the technology by $90 \%{ }^{26}$.

Although overdentures have been financed within the public health system since 2010, this technology has not yet been fully absorbed in Brazil. Out of all 5,561 Brazilian municipalities, only 34 municipalities (being 7 capital cities) have incorporated this technology up to the end of $2018^{27}$. This can be considered very low, in view of the financial support, prevalence of edentulism and capacity of the public health system. The absence of specialized dentists, lower incomes, limited number of professionals and dental specialty centers accredited for perform- 
ing procedures may influence the very low offer of this technology. Furthermore, the competition between the public and private sectors has to be recognized, with the financial return obtained in the public sector being smaller than that foreseen within the private sector. From this aspect, the increase in the offer of overdentures within the public health sector is related to the greater incentive for educating and hiring professionals who could work in the field of implant dentistry. This aspect could, however. impact the costs related to human resources.

The choice of rehabilitating edentulous individuals with a lower denture or with an overdenture can be determined by various factors, including the costs, the impact on individual's quality of life, the individual's health state and hygiene habits. Both technologies can improve the individual's quality of life by enhancing their psychological, physiological and social conditions ${ }^{28}$. The most up-to-date scientific evidence shows that rehabilitation with overdentures favors quality of life, by generating greater satisfaction, lower percentage of disuse and greater masticatory efficiency ${ }^{29-31}$. This is particularly important, because overdentures reduce the negative impacts that occur with lowerdentures, especially by improving stability and masticatory efficiency, substantially decreasing the percentage of disuse. Moreover, overdentures present improved biomechanical properties in relation to retention, hydrostatic pressure, stability and

\section{Collaborations}

DFB Cavalcante, AC Pereira and GMB Ambrosano conceptualized and designed the study. DFB Cavalcante, LF Probst, YW Cavalcanti and AC Pereira collected and analyzed data. DFB Cavalcante and LF Probst drafted the manuscript. YW Cavalcanti, AC Pereira and GMB Ambrosano revised and gave contributed for important intellectual content. All authors revised and approved the final version of the manuscript. All authors contributed significantly for taking part at manuscript's authorship. occlusion ${ }^{17,31}$. Finally, a national study shows that overdentures have a better cost-effectiveness ratio, which should be considered for managers' decision-making ${ }^{32}$.

Among the limitations towards cost estimations, we can mention a variation in the costs in different regions of the country, range of budget in public bidding, multiple suppliers and lobbies that surround the health inputs of purchasing processes and others. We control these possible variations by developing a sensitivity analysis with scenarios ranging from $20 \%$ more to $20 \%$ less in total $\operatorname{costs}^{23}$. In addition, we established the clinical stages of the two technologies and the number of sessions using a panel of experts. This can obviously be a problem; however, this procedure is standard because in some cases either the information does not exist or there are multiple ways to establish a protocol. Opinion of experts reduces the possibility of bias.

In conclusion, we affirm that costs with lower dentures and overdentures are compatible with the financial incentives provided by the Brazilian public health system. According to the micro-costing technique, both technologies receive appropriate incentives from the Ministry of Health for their manufacturing. Overdenture technology involves good cost-effectiveness and cost-benefit ratio and may be self-financed by the municipalities through the federal government incentives, and could improve the quality of life of edentulous individuals.

\section{Acknowledgments}

The authors thank Dr. Marco Antonio Tridapalli Mafra and Dr. Manuel Henrique de Medeiros for advice and technical support on the clinical protocol construction for this study. 


\section{References}

1. Campos GWS. A defesa do SUS depende do avanço da reforma sanitária. Interface (Botucatu) 2018; 22(64):58.

2. Sander M, Oxlund B, Jespersen A, Krasnik A, Mortensen EL, Westendorp RG, Rasmussen LJ. The challenges of human population ageing. Age Ageing 2015; 44(2):185-187.

3. Rocha Filho FS, Silva MG. Costs with personnel and productivity analysis of family health program teams in Fortaleza, Ceará. Cien Saude Colet 2009; 14(3):919928.

4. Macêdo MS, Chaves SC, Fernandes AL. Investments and costs of oral health care for Family Health Care. Rev Saude Publica 2016; 50:41.

5. Ferreira CA, Loureiro CA. The costs of implementing and operating an oral health service from the perspective of the service and society. Cad Saude Publica 2008; 24(9):2071-2080.

6. Griffin SO, Jones JA, Brunson D, Griffin PM, Bailey WD. Burden of oral disease among older adults and implications for public health priorities. Am J Public Health 2012; 102(3):411-418.

7. Godoi H, Mello AL, Caetano JC. An oral health care network organized by large municipalities in Santa Catarina State, Brazil. Cad Saude Publica 2014; 30(2):318-332.

8. Brasil. Ministério da Saúde (MS). Secretaria de Atenção à Saúde. Secretaria de Vigilância em Saúde. Projeto SB Brasil 2010: Pesquisa Nacional de Saúde Bucal: resultados principais. Brasília: MS; 2012.

9. Pereira AC, Frias AC, Vieira V. Pesquisa estadual de saúde bucal: relatório final. Águas de São Pedro: Livronovo; 2016.

10. Thomason JM, Kelly SA, Bendkowski A, Ellis JS. Two implant retained overdentures--a review of the literature supporting the McGill and York consensus statements. J Dent 2012; 40(1):22-34.

11. Misch C. Contemporary implant dentistry. $3^{\mathrm{a}} \mathrm{ed}$. Birgmingham: Livraria Santos EditoraLtda; 2011.

12. Bomfim RA, Frias AC, Cascaes AM, Pereira AC. Functional dentition and associated factors in Brazilian elderly people: A multilevel generalised structural equation modelling approach. Gerodontology 2018; 35(4):350-358.

13. Brasil. Ministério da Saúde (MS). Portaria no 1.825 , de 24 de agosto de 2012. Altera o valor dos procedimentos de prótese dentária na Tabela de Procedimentos, Medicamentos e OPM do SUS e estabelece recursos anuais a serem incorporados ao Teto Financeiro Anual de Média e Alta Complexidade dos Estados, Municípios e Distrito Federal para confecção de próteses dentárias nos Laboratórios Regionais de Próteses Dentárias (LRPD). Diário Oficial da União; 2012.

14. Brasil. Ministério da Saúde (MS). Secretaria de Atenção à Saúde. Coordenação Geral de Saúde Bucal. Nota técnica: Portaria SAS 718 [Internet]. 2010 [acessado 2019 fev 20]. Disponível em: http://www.sgc.goias. gov.br/upload/links/arq_468_nota_portaria718_sas4. pdf.

15. Brasil. Ministério da Saúde (MS). Secretaria de Atenção à Saúde. Coordenação Geral de Saúde Bucal. Nota Técnica $n^{\circ} 23$ [Internet]. 2017 [acessado $2019 \mathrm{fev} 20$ ]. Disponível em: http://189.28.128.100/dab/docs/geral/ passo_a_passo_ceo.pdf.
16. Araújo MMC, Martins MR, Soares ARS, Carvalho LRA, Gomes VE, Ferreira EF, Cota LOM, Senna MIB, Ferreira RC. Relationship Between Quality of Complete Dentures and User Satisfaction at 1 and 5 Years Postinsertion. Int J Prosthodont 2018; 31(31):271-279.

17. Volpato C, Garbelotto L, Zani I, Vasconcellos D. Próteses Odontológicas - Uma Visão Contemporânea - Fundamentos e Procedimentos. São Paulo: Santos; 2012.

18. Chen J, Ahmad R, Suenaga H, Li W, Swain M, Li Q. A comparative study on complete and implant retained denture treatments: a biomechanics perspective. J Biomech 2015; 48(3):512-519.

19. Cardoso RG, Melo LA, Barbosa GA, Calderon PD, Germano AR, Mestriner Junior W, Carreiro AD. Impact of mandibular conventional denture and overdenture on quality of life and masticatory efficiency. Braz Oral Res 2016; 30(1):e102.

20. Papaspyridakos P, Chen CJ, Chuang SK, Weber HP, Gallucci GO. A systematic review of biologic and technical complications with fixed implant rehabilitations for edentulous patients. Int J Oral Maxillofac Implants 2012; 27(1):102-110.

21. Della Vecchia MP, Leles CR, Cunha TR, Ribeiro AB, Sorgini DB, Muglia VA, Reis AC, Albuquerque Jr RF, Souza RF. Mini-Implants for Mandibular Overdentures: Cost-Effectiveness Analysis alongside a Randomized Trial. JDR Clinical Translational Res 2017;3(1):4756.

22. Machado FCA, Costa APS, Pontes ALB, Lima KC, Ferreira MAF. Daily difficulties associated with full conventional dentures. Cien Saude Colet 2013; 18(10):3091-3100.

23. Brasil. Ministério da Saúde (MS). Secretaria de Ciência, Tecnologia e Insumos Estratégicos. Departamento de Ciência e Tecnologia. Diretrizes metodológicas: análise de impacto orçamentário: manual para o Sistema de Saúde do Brasil. Brasília: MS; 2012.

24. Probst LF, Cavalcante DFB, Pereira AC. Como tomar uma decisão racional na gestão em saúde? Noções básicas de economia da saúde. In: Pereira AC, Bulgareli JV, Testoni G, Cavalcante DFB. Guia Prático da gestão Pública em Saúde. Piracicaba: ADM Gestão em Educação e Saúde; 2017.

25. Raghoebar GM, Meijer HJ, van't Hof M, Stegenga B, Vissink A. A randomized prospective clinical trial on the effectiveness of three treatment modalities for patients with lower denture problems. A 10 year follow -up study on patient satisfaction. Int J Oral Maxillofac Surg 2003; 32(5):498-503.

26. Nogueira TE, Aguiar FMO, de Barcelos BA, Leles CR A 2-year prospective study of single-implant mandibular overdentures: Patient-reported outcomes and prosthodontic events. Clin Oral Implants Res 2018; 29(6):541-550.

27. Brasil. Ministério da Saúde (MS). Departamento de Informática do SUS (DATASUS) [Internet]. [acessado 2019 fev 20]. Disponível em: http://datasus.saude.gov. $\mathrm{br} /$.

28. Hebling E, Pereira AC. Oral health-related quality of life: a critical appraisal of assessment tools used in elderly people. Gerodontology 2007; 24(3):151-161. 
29. Vogel R, Smith-Palmer J, Valentine W. Evaluating the health economic implications and cost-effectiveness of dental implants: a literature review. Int J Oral Maxillofac Implants 2013; 28(2):343-356.

30. Barão VA, Delben JA, Lima J, Cabral T, Assunção WG. Comparison of different designs of implant-retained overdentures and fixed full-arch implant-supported prosthesis on stress distribution in edentulous mandible--a computed tomography-based three-dimensional finite element analysis. J Biomech 2013; 46(7):1312-1320.

31. Dantas IS, Souza MB, Morais MH, Carreiro AF, Barbosa GA. Success and survival rates of mandibular overdentures supported by two or four implants: a systematic review. Braz Oral Res 2014; 28:74-80.

32. Probst LF, Vanni T, Cavalcante DFB, Silva ET, Cavalcanti YW, Passeri LA, Pereira, AC. Cost-effectiveness of implant-supported dental prosthesis compared to conventional dental prosthesis. Rev Saude Publica 2019; 53:s1518-8787.

Article submitted 15/07/2019

Approved 08/06/2020

Final version submitted 10/06/2020

Chief editors: Romeu Gomes, Antônio Augusto Moura da Silva 